\title{
DIREITOS FUNDAMENTAIS PROCESSUAIS E O PRINCÍPIO DA COOPERAÇÃO NO NOVO CÓDIGO DE PROCESSO CIVIL
}

\section{Dhebora Mendonça de Cerqueira}

Graduada em Direito pela Universidade Federal de Sergipe (São Cristóvão/SE). Especialista em Direito Processual Civil pela Faculdade Damásio (Aracaju/SE). Advogada.

\section{Flávia Moreira Guimarães Pessoa}

Doutora em Direito Público. Pós-Doutoranda pela Universidade Federal da Bahia (Salvador/ BA). Professora do Mestrado em Direito da Universidade Federal de Sergipe (São Cristóvão/ SE) e em Direitos Humanos da Universidade Tiradentes (Aracaju/SE). Juíza do Trabalho do TRT/20 ${ }^{a}$ Região (Aracaju/SE).

\begin{abstract}
Resumo: O artigo busca analisar o princípio da cooperação, previsto no novo Código de Processo Civil, à luz da hermenêutica concretizadora dos direitos fundamentais processuais. Para tanto, serão analisados os contornos normativos sobre o tema, especialmente no Direito brasileiro, mas sem descuidar do histórico dos princípios no Direito Comparado. Buscar-se-á, ainda, a exposição do pensamento de consagrados doutrinadores que se debruçaram sobre o tema. 0 princípio da cooperação surge como terceiro molde de estruturação processual, ao lado dos tradicionais modelos adversarial e inquisitivo. Trata-se o processo colaborativo da forma mais adequada de compatibilizar a justiça e a efetividade das decisões, garantindo a materialização das normas fundamentais do processo. 0 acesso à justiça, o devido processo legal, a razoável duração do processo e o contraditório efetivo são exemplos de princípios, examinados neste trabalho, que possuem estreito vínculo com a cooperação. De diversas formas, a colaboração entre os sujeitos processuais viabiliza a aplicação desses direitos fundamentais. Portanto, fica evidente que o princípio cooperativo foi a escolha mais apropriada para orientar o Direito Processual brasileiro e, se aplicado da forma proposta, acarretará bons resultados práticos.
\end{abstract}

Palavras-chave: Direitos fundamentais processuais. Novo Código de Processo Civil. Princípio da cooperação.

Sumário: Introdução - 1 Princípio da cooperação no novo CPC - 2 Princípios constitucionais do processo - 3 Princípio da cooperação e concretização dos direitos fundamentais do processo - Conclusão - Referências

\section{Introdução}

O modelo cooperativo de estruturação do processo foi adotado pelo novo Código de Processo Civil brasileiro, que revolucionou o sistema de prestação jurisdicional no país. O maior objetivo do processo civil brasileiro, atualmente, é 
concretizar as normas fundamentais do processo, a fim de obter desfecho justo e efetivo para os conflitos que são apresentados ao Estado-juiz.

Este artigo tem o escopo de analisar o princípio da cooperação previsto no novo código e de enfatizar os principais aspectos da sua aplicabilidade, à luz da concretização dos direitos fundamentais processuais.

Para tanto, serão analisadas as balizas normativas que delimitam a matéria, sem descuidar da análise histórica dos institutos no Direito Comparado. O enfoque, no entanto, está na construção doutrinária acerca do tema proposto, que será apresentada durante todo o trabalho, tendo em vista a amplitude conceitual e a importância prática dos assuntos trazidos em cada tópico.

Inicialmente, abordar-se-á o alcance do princípio da cooperação no recente diploma processual civil brasileiro, distinguindo este modelo estrutural dos tradicionais modelos adversarial e inquisitivo. Compete, ainda, analisar os deveres anexos de cooperação que se encontram espalhados por diversos dispositivos da legislação processual.

Em seguida, a apreciação recairá sobre os direitos fundamentais referentes ao Direito Processual e suas influências na idealização de um procedimento equitativo e participativo. Os princípios especialmente examinados serão o acesso à justiça, o devido processo legal, a razoável duração do processo e o contraditório efetivo.

A terceira e última parte do trabalho consiste em verificar de que maneira a aplicação prática do princípio da cooperação pode conduzir à concretização dos direitos fundamentais do processo.

A relevância do estudo ultrapassa o fato de ser novidade a disposição expressa do princípio no Código de Processo Civil. O mais importante é que a cooperação alcança todas as fases, todos os atos e todos os sujeitos do processo, além de ser a única maneira de compatibilizar a celeridade que se espera do procedimento e a qualidade da prestação jurisdicional.

As ideias de democracia, de efetividade, de lealdade e de celeridade só encontram harmonia dentro do processo se este for pautado pela colaboração entre os sujeitos que o integram - o que inclui o próprio órgão jurisdicional. Indiscutível, portanto, o grande valor do princípio colaborativo para o alcance dos direitos fundamentais do processo e para a obtenção de desfecho justo e efetivo para as contendas judiciais.

\section{Princípio da cooperação no novo CPC}

Longe de configurar mera reforma do diploma anterior, o Código de Processo Civil de 2015 representa radical transformação do sistema processual civil brasileiro, 
ao concentrar toda sua lógica na materialização dos direitos fundamentais e na busca pelo provimento jurisdicional justo e efetivo.

A compatibilização entre justiça e efetividade perpassa o embate prático entre a qualidade substancial e a duração da prestação jurisdicional. Diante desse conflito, a opção legislativa mais equilibrada seria a adoção do processo colaborativo, em que todos os sujeitos processuais - partes, magistrado, peritos, auxiliares etc. - lançassem mão da lealdade, da boa-fé e do diálogo, a fim de fornecer ao processo bases sólidas para a construção do desfecho apropriado.

Com o objetivo de eliminar protagonismos, o Legislador consagrou o princípio da cooperação no primeiro capítulo da nova lei, o qual elenca as normas fundamentais do processo civil. De acordo com o dispositivo, "todos os sujeitos do processo devem cooperar entre si para que se obtenha, em tempo razoável, decisão de mérito justa e efetiva" (art. 6ํ, CPC/2015).

O destaque topográfico é essencial para estabelecer um novo paradigma, desatrelado do contraponto entre normas do modelo inquisitivo e normas do modelo adversarial de estruturação do processo.

\subsection{Modelo inquisitivo, modelo adversarial e processo cooperativo}

A doutrina processualista ocidental reconhece dois modelos antagônicos de estruturação do processo quanto ao protagonismo na sua condução: o modelo adversarial e o modelo inquisitivo.

No modelo adversarial, de um lado, as partes administram o processo e atuam como centro da relação jurídica travada, restando ao magistrado o papel singular de decidir o conflito. Torna-se nítido o protagonismo das partes diante de inércia do órgão jurisdicional. De outro lado, o modelo inquisitivo destaca sobremaneira a atuação oficial do órgão jurisdicional, que desponta como principal ator na condução do processo, menosprezando o papel das partes naquele contexto.

Apesar de opostos, os modelos dificilmente serão identificados de forma isolada em um ordenamento jurídico. O que ocorre é a combinação de atos adversariais e de atos inquisitoriais em procedimentos complexos. A fase de propositura, por exemplo, pode seguir o molde adversarial, com maior relevância da parte, que define os limites objetivos da demanda, e, posteriormente, no mesmo processo, pode a fase de instrução ser amplamente conduzida pelo magistrado, nos padrões inquisitivos.

Entretanto, ao lado do modelo inquisitivo e do modelo adversarial, surge uma terceira forma de estruturação processual. Trata-se do processo cooperativo, lastreado no devido processo legal, na boa-fé processual e no contraditório efetivo. 
Originado na Alemanha e com grande incidência no Direito português, o princípio da cooperação compreende o órgão jurisdicional na qualidade de sujeito da relação processual, juntamente com as partes, a fim de que determinem, todos eles, o ritmo do processo de forma equilibrada, paritária. Entre os sujeitos processuais, portanto, não há protagonismo, mas democracia e comparticipação.

Foi essa a opção do novo Código de Processo Civil brasileiro: o processo cooperativo. Independentemente da fase em que se encontre, o processo será conduzido de forma democrática por todos os seus sujeitos. 0 acolhimento do modelo policêntrico - em que não há um único sujeito no centro do processo adequa-se à atual fase metodológica do Direito Processual, justamente pelo nexo perfeito entre normas processuais e direitos fundamentais.

O Estado Democrático de Direito, constitucionalmente consagrado, exige a estruturação de um processo garantidor. A cooperação, enquanto modelo mais apropriado para alcançar esse escopo, traz consigo as ideias de participação, de lealdade, de isonomia e de democracia, vez que não há personagens mais importantes e menos importantes, mas, simplesmente, personagens aptos e obrigados a colaborar com a regular marcha processual.

Esclareça-se, todavia, que a cooperação não indica que as partes devem se ajudar reciprocamente para atingirem juntas o desfecho processual mais justo. Os interesses das partes permanecem colidentes e cada uma delas defenderá seu suposto direito até o fim, sem que isso configure afronta ao princípio cooperativo. 0 alcance da colaboração pretendida não se aproxima da utopia, como pode parecer se vislumbrado nesse aspecto.

O real significado do princípio da cooperação é a concretização do diálogo entre os sujeitos do processo, gerando um ambiente de respeito ao contraditório, na busca da resolução efetiva do conflito. Portanto, o julgamento vazio, sem a verdadeira extinção da desavença, não atinge o objetivo do processo garantidor, uma vez que a efetividade da prestação jurisdicional é necessariamente condicionada à construção participativa das decisões.

Impõe-se, para tanto, obediência a certos deveres recíprocos entre os sujeitos do processo, anexos às regras procedimentais elementares, que conferem aos atos a medida imprescindivel de coparticipação para que se caracterize a esperada cooperação processual.

\subsection{Deveres processuais decorrentes do princípio da cooperação}

Diante da estreita relação entre o princípio cooperativo e o princípio da boa-fé objetiva, tem-se que os deveres anexos de cooperação processual aproveitam a 
construção doutrinária - altamente consolidada - acerca dos deveres laterais decorrentes da boa-fé no Direito Privado. É possível e correto, portanto, caracterizar as condutas exigidas pelo princípio cooperativo como verdadeiras manifestações de lealdade no âmbito processual.

São deveres de cooperação: o dever de esclarecimento, o dever de consulta ou de diálogo, o dever de prevenção e o dever de auxílio ou de adequação.

O dever de esclarecimento é uma via de mão dupla, porquanto vincula, por um lado, as partes com relação ao magistrado e, por outro lado, o magistrado com relação às partes.

$\mathrm{Na}$ primeira hipótese, vislumbra-se o dever das partes de demandar com clareza e de responder objetivamente aos questionamentos e às dúvidas apresentadas pelo órgão jurisdicional, diante de eventual obscuridade. Na segunda, em sentido inverso, é o órgão jurisdicional que deve se fazer entender, fundamentando minuciosamente as suas decisões e dirimindo quaisquer questionamentos apresentados pelas partes.

$\mathrm{O}$ que se pretende afastar com o dever de esclarecimento, por conseguinte, são as dúvidas dos sujeitos processuais. Quanto mais claro for o processo, quanto mais lúcido for o entendimento dos sujeitos, mais democrático será o desfecho da relação, ampliando as chances de real solução do conflito.

Só é capaz de contribuir significativamente com a resolução da controvérsia a parte que conhece todas as peculiaridades da causa e, do mesmo modo, apenas tem condições de decidir com acerto o juiz consciente, esclarecido e convicto a respeito do que foi pedido e do que foi provado.

O novo Código de Processo Civil, em seu artigo 357, parágrafo 3o , estabelece expressamente o dever de esclarecimento das partes. Consoante o dispositivo:

Se a causa apresentar complexidade em matéria de fato ou de direito, deverá o juiz designar audiência para que o saneamento seja feito em cooperação com as partes, oportunidade em que o juiz, se for o caso, convidará as partes a integrar ou esclarecer suas alegações (art. 357, §3으, CPC/2015).

Quanto ao dever de esclarecimento do juiz, dispõe o artigo 489, parágrafo 2ํㅡ, do novo diploma processual brasileiro:

No caso de colisão entre normas, o juiz deve justificar o objeto e os critérios gerais da ponderação efetuada, enunciando as razões que autorizam a interferência na norma afastada e as premissas fáticas que fundamentam a conclusão (art. 489, §2º, CPC/2015). 
O dever de esclarecimento, no entanto, é apenas uma das formas de expressão do princípio colaborativo. Outro elemento do conjunto dos deveres anexos de cooperação é o dever de consulta ou de diálogo.

Trata-se de regra que concretiza o princípio do contraditório efetivo, uma vez que veda ao juiz a prolação de decisão, ainda que conhecível de ofício, sem prévia oitiva das partes.

Se o dever de esclarecimento concede aos sujeitos o direito de conhecer o processo e de ter eliminadas as suas dúvidas, o dever de consulta autoriza que, uma vez esclarecidas as questões, as partes possam influenciar efetivamente nas decisões do órgão jurisdicional.

O ordenamento português, o francês e o italiano já adotam essa regra em seus diplomas processuais e acabaram por influenciar o Direito brasileiro no mesmo sentido. O artigo 9 do novo Código de Processo Civil brasileiro afirma que "não se proferirá decisão contra uma das partes sem que ela seja previamente ouvida". Na mesma linha, o artigo 10 informa que "o juiz não pode decidir, em grau algum de jurisdição, com base em fundamento a respeito do qual não se tenha dado às partes a oportunidade de se manifestar, ainda que se trate de matéria sobre a qual deva decidir de ofício".

Consagra-se, portanto, a vedação à decisão-surpresa. Quando prolatada sem observância do contraditório, a decisão acarreta, na menos prejudicial das hipóteses, o recrudescimento da recorribilidade, afrontando a celeridade e a economia processual. A oitiva prévia das partes legitima a decisão e evita inconformismos posteriores.

Antecipar a discussão é medida das mais eficientes para garantir a efetividade da participação e a celeridade da marcha processual. Sem contar que o diálogo contribui também para o esclarecimento dos sujeitos do processo, viabilizando o caráter democrático que se espera da relação jurídica.

Além do esclarecimento e da consulta, decorre do princípio da cooperação o dever de prevenção, direcionado ao órgão jurisdicional, que deve buscar o máximo aproveitamento dos atos processuais praticados, evitando nulidades diante de defeitos sanáveis.

O professor Lúcio Grassi de Gouveia aponta quatro áreas em que se aplica o dever de prevenção. São elas: explicitação de pedidos pouco claros, integração de lacunas da exposição de fatos relevantes, necessidade de adequar o pedido formulado à situação concreta e sugestão de certa atuação (GOUVEA, 2011, p. 376).

Em todo caso, o objetivo é oportunizar à parte a correção do defeito, como forma de evitar a repetição do ato ou até a extinção do processo por nulidade que poderia ter sido eliminada.

0 artigo 321 do novo diploma processual brasileiro traz hipótese de aplicação do dever de prevenção ao preceituar que: 
O juiz, ao verificar que a petição inicial não preenche os requisitos dos arts. 319 e 320 ou que apresenta defeitos e irregularidades capazes de dificultar o julgamento de mérito, determinará que o autor, no prazo de 15 (quinze) dias, a emende ou a complete, indicando com precisão o que deve ser corrigido ou completado (art. 321, caput, $\mathrm{CPC} / 2015)$.

Por fim, existe o dever de auxílio ou de adequação, consistente em regras de eliminação das dificuldades procedimentais, a fim de tornar o processo mais equilibrado. Garante-se, assim, a isonomia entre os sujeitos através da adaptabilidade do procedimento às particularidades da causa, flexibilizando normas de conteúdo excessivamente formalista com o objetivo de facilitar o desempenho dos atos processuais pelas partes.

São muitas as hipóteses do novo Código Processual Civil brasileiro que consagram o dever de auxílio. É o caso do artigo 373, parágrafo 1ํㅜ, que estabelece:

Nos casos previstos em lei ou diante de peculiaridades da causa relacionadas à impossibilidade ou à excessiva dificuldade de cumprir o encargo nos termos do caput ou à maior facilidade de obtenção da prova do fato contrário, poderá o juiz atribuir o ônus da prova de modo diverso, desde que o faça por decisão fundamentada, caso em que deverá dar à parte a oportunidade de se desincumbir do ônus que lhe foi atribuído (art. 373, §1ํㅡ, CPC/2015).

$\mathrm{O}$ artigo 139, inciso VI, inclui o auxílio no rol dos deveres do juiz. Aponta o dispositivo:

O juiz dirigirá o processo conforme as disposições deste Código, incumbindo-lhe dilatar os prazos processuais e alterar a ordem de produção dos meios de prova, adequando-os às necessidades do conflito de modo a conferir maior efetividade à tutela do direito (art. 139, VI, CPC/2015).

No mesmo sentido, o artigo 437, parágrafo $2^{\circ}$, prevê que “poderá o juiz, a requerimento da parte, dilatar o prazo para manifestação sobre a prova documental produzida, levando em consideração a quantidade e a complexidade da documentação".

O dever de auxílio, portanto, impõe a supressão dos obstáculos presentes entre a propositura da ação e o desfecho efetivo que se procura alcançar. Cada processo é único e deve ser analisado com atenção às suas particularidades, 
razão que pode justificar a dilatação de prazos, a inversão de ônus e quaisquer outras alterações procedimentais que suavizem o trajeto até a prestação jurisdicional definitiva.

Apesar da distinção entre dispositivos que consagram deveres de esclarecimento, de consulta, de prevenção e de auxílio, certo é que o princípio da cooperação é completo e possui eficácia independentemente de regras concretizadoras no ordenamento.

Os deveres anexos de cooperação sistematizam o princípio, evidenciam a sua necessidade, mas não condicionam a sua aplicabilidade, porquanto esta decorre diretamente das normas fundamentais de acesso à justiça, de devido processo legal, de duração razoável e de contraditório. Ao lado dos princípios constitucionais do processo, a cooperação contribui para a construção de uma atividade jurisdicional efetiva, célere e democrática, própria da linha metodológica neoprocessualista.

\section{Princípios constitucionais do processo}

O ordenamento jurídico brasileiro é, hodiernamente, um sistema de normas composto por regras e por princípios. Harmonizar a coexistência dessas duas espécies normativas significa, sobretudo, preservar a segurança jurídica do ordenamento sem abrir mão dos valores consagrados a partir da visão constitucional do Direito.

Muito mais do que simples técnicas de colmatação de lacunas, os princípios passam a constituir o próprio fundamento das regras jurídicas, levando em si toda a carga axiológica que se espera do Direito contemporâneo.

\subsection{Direito fundamental ao acesso à justiça}

Entre os séculos XVIII e XIX, ápice dos Estados Liberais adeptos ao positivismo jurídico, o direito de acesso à justiça restringia-se à mera possibilidade de propositura ou de contestação de uma ação judicial.

O liberalismo caracteriza-se pela ausência do Estado na vida das pessoas. Consequentemente, embora fosse reconhecido o direito formal de acesso à justiça, as impossibilidades fáticas - geralmente econômicas - afastavam a população das instituições judiciárias, sem que o Estado interviesse minimamente para garantir o exercício desse direito.

Com o desenvolvimento do welfare state, a partir de meados do século XX, tornou-se evidente que a inércia estatal em não atuar para garantir o exercício dos 
direitos básicos da sociedade simplesmente anulava a previsão desses direitos em termos de utilidade prática.

Desse modo, para que o Estado Social pudesse assegurar os direitos da população de forma efetiva, fez-se imprescindivel a garantia substancial do acesso à justiça - que transcende a simples possibilidade de postular ou de se defender em juízo e atinge, com o desenvolvimento da ciência processual moderna, estreita relação com o conteúdo material das decisões e com as demais garantias constitucionais do processo.

No entanto, o efetivo acesso à justiça esbarra em alguns obstáculos de difícil transposição, conforme assinalam Mauro Cappelletti e Bryant Garth, que dedicaram uma obra completa à análise desse princípio. O primeiro dos obstáculos é o custo do litígio (CAPPELLETTI; GARTH, 1988, p. 15).

Despesas com custas processuais, com honorários advocatícios e com ônus da sucumbência podem, por muitas vezes, desencorajar o titular de um direito a buscar a proteção judicial devida. Em causas de pequeno porte econômico, em que o montante das despesas atinge - ou, por vezes, até supera - o proveito da parte, o obstáculo revela-se ainda maior.

Outro problema que acarreta o aumento das despesas processuais é a longa duração do processo judicial. Em decorrência da morosidade, é comum o abandono de causas e a formulação de acordos desvantajosos para a parte que tem direito à prestação jurisdicional favorável.

Além das altas despesas, a inexperiência, a falta de conhecimento jurídico mínimo, a indisposição para recorrer ao Poder Judiciário e a descrença nas instituições e nos advogados são aspectos que sempre afastaram a população do efetivo acesso à justiça.

Tendo em vista a existência dos obstáculos apresentados e a constante necessidade de superá-los, Mauro Cappelletti e Bryant Garth ressaltaram três momentos relevantes para o real alcance do direito fundamental em análise, os quais denominaram “ondas de acesso à justiça”: a assistência judiciária, a representação jurídica para os interesses difusos e o enfoque de acesso à justiça propriamente dito (CAPPELLETTI; GARTH, 1988, p. 31).

Atualmente, o direito fundamental ao acesso à justiça é encarado como acesso ao juízo, ao juiz e a decisões justas, cumulativamente. Muito mais do que a simples faculdade de ajuizar ou de contestar uma demanda perante o Poder Judiciário, a dimensão atual do acesso à justiça envolve obediência às normas procedimentais (princípio do devido processo legal) e possibilidade de contribuir efetivamente para a formação do convencimento do juiz (princípio do contraditório efetivo), com o objetivo de alcançar justiça ao final do processo. 
Antônio Cintra, Cândido Rangel Dinamarco e Ada Pellegrini Grinover atribuem ao acesso à justiça o sentido de acesso à ordem jurídica justa, expressão doutrinária que entendem mais apropriada (CINTRA; DINAMARCO; GRINOVER, 2009, p. 39).

A previsão contida na Constituição Federal Brasileira de 1988 segundo a qual "a lei não excluirá da apreciação do Poder Judiciário lesão ou ameaça a direito" (artigo 5으, inciso XXXV) garante, portanto, apenas uma das vertentes do direito fundamental de acesso à justiça: a possibilidade de demandar em juízo e de obter uma resposta jurisdicional.

Todavia, é certo que o acesso à justiça apenas será atingido em sua plenitude quando os empecilhos econômicos, culturais, psicológicos e jurídicos que o permeiam forem definitivamente superados.

\subsection{Direito fundamental ao devido processo legal}

Originado na inglesa Carta Magna do Rei João Sem Terra, em 1215, o devido processo legal consiste, até os dias atuais, em um dos mais importantes princípios consagrados, tendo em vista a sua capacidade de proteger tantos outros direitos fundamentais de grande relevância, a exemplo da liberdade, da igualdade substancial, da contenção do poder público e da justiça.

Com a introdução dos ideais ingleses no direito das suas colônias da América do Norte, o due process of law torna-se, inicialmente, uma construção do sistema da common law. Contudo, a partir da constitucionalização do direito evidenciada na segunda metade do século XX, com a ascensão dos princípios à categoria de normas jurídicas vinculantes e com a preocupação em garantir os direitos fundamentais da população, o devido processo legal encontrou respaldo jurídico em escala mundial.

Ao longo da história, o significado deste princípio ganhou diferentes contornos. Atualmente, pode ser concebido de duas formas. A primeira delas é o devido processo legal formal, relativo às garantias de natureza procedimental, a exemplo da duração razoável do processo, do contraditório, da ampla defesa, dentre outras.

Existe ainda o devido processo legal substancial e, acerca desta vertente, cabem considerações mais profundas. É que, enquanto direito fundamental substantivo, este princípio transcende os limites processuais meramente formais e atinge o conteúdo material das decisões.

Inerentes ao devido processo legal substancial são os deveres de proporcionalidade e de razoabilidade, enquanto parâmetros de contenção do poder do Estado não só no âmbito do Poder Judiciário, mas também nas esferas legislativa e executiva. 
A partir da cláusula geral do devido processo legal - ao qual, intrinsecamente, relaciona-se a contenção do poder do Estado -, a atividade jurisdicional, a função legislativa e a administração pública são compulsadas a observar a adequação, a necessidade e a estrita proporcionalidade dos seus atos, a fim de que seja evitada a prática de arbitrariedades. José Joaquim Gomes Canotilho sintetiza esses deveres na expressão “princípio da proibição do excesso" (CANOTILHO, 2003, p. 272).

Nesse aspecto, evidenciada está a preocupação com o conteúdo dos atos administrativos, a qual ultrapassa radicalmente as fronteiras procedimentais ou meramente formais. Segue, portanto, a mesma linha ideológica implantada pelo neoconstitucionalismo, com a força normativa da constituição e com a valorização de princípios axiologicamente ricos.

Destaca o professor Ruitemberg Nunes Pereira, em sua obra acerca do devido processo legal substancial, que a substancialização do devido processo evoluiu paralelamente com a materialização da norma constitucional, que caminhou no sentido de abandonar o mero formalismo e atingir o status de constituição viva (PEREIRA, 2005, p. 239).

Observa-se, então, mais uma perspectiva da hermenêutica constitucional contemporânea. Contudo, importa advertir que, para que os direitos fundamentais, constitucionalmente consagrados, possam influir efetivamente no modo de vida da sociedade e transformar a concepção jurídica nacional, faz-se necessária a atuação positiva do Judiciário, enquanto poder incumbido de exercer o controle de constitucionalidade da nossa legislação.

A função do magistrado adquire, neste momento da ciência processual, papel de destaque em razão da responsabilidade a ele conferida pela atribuição de diversos poderes, como os de admissão, de adequação do procedimento, de condução da instrução processual, de julgamento, de coerção e de verificação casuística da constitucionalidade.

Se o ensino jurídico brasileiro prepara satisfatoriamente os futuros magistrados para assumirem tamanha responsabilidade de forma madura, correta e racional, trata-se de outra questão que, apesar de relevante, não incumbe ao estudo ora apresentado.

O intuito aqui é apontar o desenvolvimento do princípio da cooperação e enfatizar a influência dos princípios constitucionais na formação da ciência processual contemporânea, na busca de aproximar, cada vez mais, o direito da real e efetiva justiça.

\section{3 Direito fundamental à razoável duração do processo}

A razoável duração do processo, assim como os demais princípios apresentados neste trabalho, está prevista no rol de direitos e garantias fundamentais da 
Constituição Federal Brasileira de 1988, nos seguintes termos: “a todos, no âmbito judicial e administrativo, são assegurados a razoável duração do processo e os meios que garantem a celeridade de sua tramitação" (artigo 5, inciso LXXVIII).

Diante da morosidade na tramitação de processos no Judiciário, fez-se oportuna a previsão específica do direito fundamental à duração razoável em nosso ordenamento jurídico, já que, por numerosas vezes, a prestação jurisdicional tornou-se intempestiva para a parte interessada. No ano de 2004 , portanto, a Emenda Constitucional no 45 inseriu o inciso LXXVIII - supracitado - no artigo 5으 da nossa Carta Magna.

Contudo, entende a doutrina processualista que a inclusão do dispositivo só veio a reafirmar a leitura que já se fazia do inciso XXXV do mesmo artigo, o qual aborda o direito fundamental ao acesso à justiça.

Embora a necessidade dessa garantia decorra da lentidão na prestação jurisdicional, não há como confundir o direito fundamental à razoável duração com o direito à rapidez na tramitação do processo.

De acordo com a atual perspectiva da ciência processual, que valoriza o conteúdo material das decisões e o resultado justo do processo, alguns critérios devem ser observados para definir o que se pode entender por duração razoável.

A complexidade do processo, a conduta das partes e dos seus procuradores e a forma de atuação do órgão jurisdicional são parâmetros conforme os quais pode variar a noção de razoabilidade. Ocorre que o limite para que se determine a influência de tais critérios, diante do caso concreto, são subjetivos e flexíveis, o que pode tornar, vez por outra, sem efeito a garantia constitucional da duração razoável do processo.

Mais enredada se torna a questão quando confrontados a duração razoável do processo e o princípio constitucional do contraditório efetivo. Por um lado, a morosidade da justiça impôs ao Estado que promovesse os instrumentos compatíveis com a celeridade processual - e aqui não se fala em aceleração descabida, mas em tempo razoável de tramitação.

De outra banda, o contraditório efetivo garante aos litigantes a possibilidade de colaborar com o desenrolar processual, influenciando as decisões judiciais e cooperando para que o resultado seja o mais justo possível. O que deve prevalecer: a celeridade ou a obediência às demais garantias processuais?

Como exemplo, podemos observar o caso hipotético de um pai que abusa sexualmente do filho menor de idade, acerca do qual a única prova existente é uma gravação clandestina (prova ilícita).

Deve prevalecer o direito à privacidade do pai e desconsiderar-se a prova ilícita? Deve preponderar o direito à dignidade da criança e admitir-se prontamente a gravação? A tarefa jurisdicional torna-se muito mais complexa em hipóteses como essa. 
O professor Alexandre Freitas Câmara dedica parcela de uma de suas obras a esclarecer o real significado da duração razoável. Para ele, cada processo tem seu tempo - que deve ser considerado -, devendo-se evitar, aí sim, os grandes atrasos injustificados. A fim de ilustrar, o autor aponta o exemplo do automóvel que trafega pela estrada, afirmando que tanto os excessivamente lentos quanto os excessivamente velozes são perigosos. Bem assim ocorre com o processo, que se torna injusto se muito moroso e inseguro se muito rápido (CÂMARA, 2011, p. 60-61).

Conciliar o trabalho árduo de perseguir a verdade real dentro do processo judicial com a celeridade que se espera da atividade jurisdicional não é tarefa das mais fáceis, visto que o alcance da razoabilidade pretendida requer esforço intelectual e habilidade técnica para adequar a prestação a um e a outro direito fundamental.

\subsection{Direito fundamental ao contraditório efetivo}

Tradicionalmente, o direito ao contraditório consistia na possibilidade de um dos litigantes responder às alegações da parte contrária, o que corresponde ao binômio informação/reação, típico do contraditório formal. No momento processual que vivenciamos hoje, contudo, o direito de ser ouvido é a garantia mínima de participação que o princípio do contraditório pode oferecer.

A participação proporcionada pelo direito fundamental em análise configura um dos mais importantes elementos do princípio do devido processo legal. Dessa forma, certamente, não havia como manter a visão formalista do contraditório diante da substancialização do devido processo. Tanto o contraditório efetivo quanto o devido processo legal substantivo são consectários do desenvolvimento da ciência processual à luz dos direitos fundamentais constitucionalmente previstos.

A perspectiva atual do princípio do contraditório demonstra que, além do direito de ser ouvida, deve ser garantida à parte a possibilidade de influenciar a decisão do magistrado através de suas ideias e argumentos fáticos ou jurídicos. Se a parte é ouvida e o juiz desconsidera absolutamente as suas alegações, o contraditório estabelecido nada tem de efetivo.

Esse aspecto do princípio do contraditório não abrange somente o mérito da controvérsia, como bem esclarecem Alvaro de Oliveira e Daniel Miditiero, mas as questões preliminares, as provas, a fase recursal, a fase executiva, ou seja, todo o processo, em qualquer momento e em qualquer grau de jurisdição (MITIDIERO; OLIVEIRA, 2012, p. 36).

A relação que envolve o contraditório efetivo, a ampla defesa e o devido processo legal substancial destina-se ao resultado justo do processo, pautado na 
verdade real que se busca com a colaboração das partes para a decisão do juiz e com a cooperação recíproca durante todo o procedimento.

\section{Princípio da cooperação e concretização dos direitos fundamentais do processo}

Embora não haja previsão expressa do princípio cooperativo no texto constitucional, é inevitável concluir que a dimensão substancial dos direitos fundamentais do processo só pode ser plena em uma relação jurídica democrática e coparticipativa.

$\mathrm{Na}$ contramão da doutrina majoritária, alguns autores - como Lúcio Delfino e Lenio Streck - apresentam fortes reservas ao processo cooperativo. Primeiro, porque entendem que a Constituição foi clara ao assegurar o direito fundamental do contraditório aos litigantes, em processo judicial ou administrativo, e aos acusados em geral, excluindo o órgão jurisdicional. Depois, por defenderem que a inclusão do magistrado como sujeito do processo significa o fortalecimento do ativismo judicial e, consequentemente, a proliferação de autoritarismos que afastam os direitos fundamentais do processo.

Com o devido respeito aos ilustres doutrinadores, não parece que ampliar o âmbito de aplicação do princípio do contraditório possa estimular o autoritarismo e a parcialidade do magistrado. Ao contrário, trazer o juiz para um nível de paridade com as partes significa desconstruir a sensação histórica de superioridade do órgão jurisdicional em sua atuação.

O diálogo entre os sujeitos, da mesma forma que possibilita resultados mais satisfatórios às partes em sede de autocomposição, também é capaz de contribuir significativamente para a qualidade da decisão judicial a ser proferida no ambiente litigioso.

Muito embora a Constituição Federal não preveja expressamente o órgão jurisdicional como sujeito do processo, titular do direito ao contraditório, não há como negar que o novo diploma processual, ao ampliar a incidência de um princípio fundamental, não se tornou inconstitucional, mas, sim, impulsionou o espírito de proliferação dos direitos fundamentais, capazes de tornar o processo mais eficiente, mais democrático, mais justo, mais legítimo.

Não há inflação do ativismo judicial, tampouco incentivo ao autoritarismo. No modelo cooperativo de processo, o destaque do órgão jurisdicional apenas se revela no momento de proferir a decisão, uma vez que o exercício de manifestação do poder a ele atribuído é exclusivo, conforme assevera o professor Fredie Didier Júnior (DIDIER JÚNIOR, 2016, p. 351). Nas demais fases de condução do processo, no entanto, a simetria entre os sujeitos é constante, tornando-se necessária 
para garantir a ausência de protagonismos e, consequentemente, a construção democrática do desfecho da relação processual.

Como não se pode ignorar o caráter complementar entre princípios, certo é que a cooperação deve ser considerada de forma sistemática, não isolada. Os efeitos decorrentes da colaboração processual afetam diretamente importantes direitos fundamentais, como o acesso à justiça e a duração razoável do processo. Significa dizer, portanto, que os princípios dialogam entre si.

\subsection{Cooperação e acesso à justiça}

$\mathrm{O}$ artigo do novo Código de Processo Civil que apresenta o princípio colaborativo aponta, como objetivo da cooperação, a obtenção, em tempo razoável, de decisão de mérito justa e efetiva. Lido de outro modo, o dispositivo elenca a cooperação como meio para alcançar o substancial acesso à justiça.

Para lograr esse aspecto substancial, a democracia no processo é imprescindivel. É que a legitimidade do exercício da jurisdição encontra-se condicionada à efetiva participação dos sujeitos processuais, que contribuem para a solução da controvérsia de forma ampla.

O mero direito de manifestação nos autos não é capaz de garantir plenamente o contraditório, porquanto a essência desse direito fundamental pressupõe a real influência da manifestação da parte na decisão a ser proferida. Portanto, se a participação é ampla, o contraditório é efetivo e o acesso à justiça substancial torna-se concreto.

A colaboração de todos os sujeitos processuais para a formação da decisão final legitima o procedimento em sua integralidade, tendo em vista que o desfecho do processo não foi imposto ou inventado, mas, sim, construído com a interferência direta das próprias partes.

Seja através da autocomposição, seja através da colaboração processual, o importante é que as partes contribuam efetivamente para o desenrolar das suas controvérsias e não figurem no processo como coadjuvantes da atuação do órgão jurisdicional. Enquanto destinatários da prestação do Estado, os litigantes não devem ser meros expectadores do trabalho do magistrado, tampouco aguardar passivamente o fim do processo para, se for o caso, recorrer em momento posterior.

O processo é policêntrico. Não há protagonistas, não há coadjuvantes. Todos os sujeitos que compõem a relação jurídica processual devem colaborar de forma leal para que se atinja um resultado democrático e efetivo, já que a sentença, por si só, não garante a real solução do conflito. Quanto menos dúvidas, surpresas, nulidades e dificuldades, mais próximo está o acesso à justiça substancial. 
Para tanto, o princípio da cooperação é fundamental, assim como seus corolários concretizadores - dever de esclarecimento, dever de consulta, dever de prevenção e dever de auxílio. Como movimento ascendente em escada, a cooperação garante o contraditório e o contraditório garante o acesso à justiça. Essa é a perfeita configuração de um devido processo legal substancial.

\subsection{Cooperação e razoável duração do processo}

Assim como ocorre com o acesso à justiça, o direito fundamental à razoável duração do processo também recebe importante influência do princípio da cooperação. A relação entre os princípios é direta e se sustenta em diferentes vetores convergentes para o mesmo objetivo.

O primeiro vetor que conecta a cooperação e a duração razoável é a amenização da recorribilidade. Diante da colaboração de todos os sujeitos processuais para a construção de um desfecho democrático para o processo, torna-se mais raro o inconformismo, em razão da legitimidade conferida à prestação jurisdicional pela participação efetiva.

Muitas das possiveis questões que seriam aventadas em recursos posteriores podem ser dissolvidas se observado o dever de esclarecimento entre os sujeitos do processo. Tanto por parte dos litigantes, que devem se manifestar com clareza, quanto por parte do magistrado, que deve se fazer entender, o dever de esclarecimento antecipa a discussão que seria travada em âmbito recursal, trazendo-a para a fase de conhecimento.

Dessa forma, em um processo cooperativo ideal, a decisão judicial tende à correção. É que o magistrado estará consciente de todos os pormenores do litígio, uma vez que as partes foram claras e que, diante de eventual questionamento, cuidaram de dirimir as dúvidas imediatamente.

Além disso, as próprias partes também tenderão ao conformismo, pois a decisão do magistrado refletirá o resultado do diálogo proporcionado pela intensa participação e das discussões antecipadas para a fase de conhecimento, pouco ou nada restando para levar à etapa recursal.

Evidente, portanto, uma das formas de contribuição do princípio da cooperação para o direito fundamental à duração razoável. A redução da recorribilidade influi diretamente no tempo do processo, que, embora um pouco dilatado na fase de conhecimento - para possibilitar uma cognição plena e eficiente -, será significativamente economizado pela ausência de múltiplos recursos. Trata-se da legitimidade conduzindo à celeridade.

Outro vetor que relaciona a cooperação e a duração razoável é o afastamento de nulidades pelo dever de prevenção. Se o defeito processual é sanável, deve 
o juiz intimar a parte para que o corrija antes de declarar a nulidade do ato ou de extinguir o processo sem resolução do mérito.

O grande objetivo do dever de prevenção é aproveitar ao máximo os atos praticados pelas partes, evitando que devam ser repetidos - o que pode comprometer a celeridade processual - ou que o processo simplesmente termine sem que o seu principal escopo seja alcançado, qual seja, a resolução real do conflito.

Então, a partir do momento em que os vícios do processo podem ser sanados pelas próprias partes, sem decretação de nulidade, torna-se mais rápido o procedimento, em virtude da ausência de repetições supérfluas. Mais uma vez, encontram-se conectados os princípios da cooperação e da duração razoável do processo.

O terceiro vetor entre esses dois princípios é a eliminação de dificuldades procedimentais, alcançada com o dever de auxílio ou de adequação. Combate-se a morosidade resultante do excesso de formalidades inúteis, que deságuam em processos burocratizados e longos, com a adaptabilidade do procedimento às particularidades da causa. O que se busca é facilitar a atuação das partes, através da distribuição dinâmica de ônus, da dilatação de prazos ou de alguma outra flexibilização procedimental necessária para afastar obstáculos.

Em nome do devido processo legal substantivo, admite-se a adequação do procedimento como importante aliado da duração razoável do processo. 0 dinamismo social, o crescimento exponencial do número de litígios e a maior complexidade das relações interpessoais foram alguns dos fatores determinantes para o rompimento com o formalismo excessivo.

Isso não quer dizer que o procedimento padrão deixe de existir, mas que seja possível ao magistrado, desde que ouvidas as partes, adequar o procedimento, de modo a garantir observância aos princípios constitucionais do processo no plano concreto.

É nítido, portanto, que o afastamento de empecilhos à duração razoável do processo consiste em uma das principais funções do princípio da cooperação. Ao reduzir a recorribilidade, ao evitar nulidades ou ao eliminar obstáculos, a colaboração entre os sujeitos processuais contribui com a celeridade procedimental, além de preservar a garantia do devido processo legal substantivo.

\section{Conclusão}

O Código de Processo Civil de 2015 transformou radicalmente o sistema processual civil brasileiro, que se curva às normas fundamentais do processo na busca de uma prestação jurisdicional justa e efetiva. Como forma de equilibrar a 
justiça e a efetividade, optou o Legislador por adotar o princípio da cooperação, em que todos os sujeitos processuais colaboram democraticamente para a construção do desfecho apropriado.

Tradicionalmente, eram apenas dois os modelos de estruturação do processo reconhecidos pela doutrina ocidental: o modelo adversarial e o modelo inquisitivo. O primeiro é caracterizado pelo protagonismo das partes, que administram todo o processo e deixam ao juiz o papel secundário de atuar somente na decisão do conflito, quedando-se inerte nos demais momentos da condução processual. O segundo modelo, ao contrário, tem por particularidade o protagonismo do órgão jurisdicional, menosprezando o papel das partes.

Em paralelo a essas formas tradicionais, surge, na Alemanha, uma terceira espécie de estruturação processual: o processo cooperativo. Trata-se de um modelo em que o órgão jurisdicional se apresenta como sujeito do processo, juntamente com as partes, originando uma relação jurídica coparticipativa e policêntrica, sem protagonismos.

A cooperação, enquanto modelo mais apropriado para alcançar a garantia dos direitos fundamentais do processo, traz consigo as ideias de participação, de lealdade, de isonomia e de democracia, pois concretiza o diálogo entre os sujeitos, com a finalidade de lograr a efetiva resolução do conflito.

Embora a eficácia do princípio seja plena, há regras de concretização da cooperação por toda a legislação processual, que impõem deveres aos sujeitos de forma específica e ajudam a sistematizar a aplicação da colaboração no caso concreto. Os deveres de cooperação são: o dever de esclarecimento (que busca evitar dúvidas), o dever de consulta ou diálogo (que busca evitar decisões-surpresa), o dever de prevenção (que busca evitar nulidades) e o dever de auxílio ou de adequação (que busca evitar obstáculos procedimentais).

A cooperação contribui, ao lado dos princípios constitucionais do processo, para a construção de uma atividade jurisdicional efetiva, célere e democrática, própria do neoprocessualismo.

Dentre os direitos fundamentais referentes ao processo, destacam-se os direitos ao acesso à justiça, ao devido processo legal substantivo, à razoável duração do processo e ao contraditório efetivo. Através de seus respectivos âmbitos de incidência, tais princípios objetivam viabilizar um processo equitativo, com igualdade substancial entre as partes e com resultado justo.

Para tanto, o juiz deve conhecer o caso que analisa e manter as partes igualmente cientes de todos os aspectos procedimentais referentes à causa. Os litigantes, por sua vez, adquirem o importante papel de auxiliar o julgador nessa tarefa cognitiva, o que configura a extrema importância da cooperação entre os sujeitos, com a finalidade de obter o desfecho adequado para aquele caso concreto. 
A colaboração de todos os sujeitos processuais para a formação da decisão final legitima o procedimento, tendo em vista que o resultado do processo não foi imposto ou inventado, mas sim construído com a interferência direta das próprias partes.

Ao afastar os entraves à duração razoável do processo, a cooperação também garante direitos fundamentais. Reduzir a recorribilidade, evitar nulidades e eliminar obstáculos são meios através dos quais a colaboração entre os sujeitos processuais contribui com a celeridade procedimental.

Diante das diversas possibilidades de concretização de direitos fundamentais oferecidas pelo princípio da cooperação, não há dúvidas de que se trata do modelo mais adequado de estruturação processual a ser adotado no ordenamento jurídico pátrio. A participação efetiva é a única maneira de compatibilizar a duração razoável do processo com a qualidade da decisão proferida. Portanto, resta que seja aplicado nos moldes delineados para que o princípio colaborativo renda bons frutos para a atividade jurisdicional brasileira.

\section{Procedural fundamental rights and the principle of cooperation in the New Civil Procedure Code}

Abstract: The article analyzes the principle of cooperation laid down in the new Code of Civil Procedure in the light of prolific hermeneutics of procedural fundamental rights. Therefore, the normative contours will be analyzed on the subject, especially in Brazilian law, but without neglecting the history of the principles in comparative law. Search it will also exposing the thinking of established scholars who have studied the subject. The principle of cooperation emerges as the third mold procedural structure, next to the traditional adversarial and inquisitorial models. It is the collaborative process the most appropriate way to reconcile justice and the effectiveness of decisions, ensuring the realization of the fundamental rules of the process. Access to justice, due process, the reasonable duration of the process and effective contradictory are examples of principles examined in this work, which have close ties with the cooperation. In many ways, the collaboration between the procedural subject enables the application of these fundamental rights. Therefore, it is evident that the cooperative principle was the most appropriate choice to guide the Brazilian procedural law and, if implemented as proposed, will lead to good practical results.

Keywords: Procedural fundamental rights. New Code of Civil Procedure. Principle of cooperation.

Contents: Introduction -1 Principle of cooperation in the new CPC $\mathbf{- 2}$ Constitutional principles of the process - 3 Principle of cooperation and realization of procedural fundamental rights - Conclusion - References

\section{Referências}

ALEXY, Robert. Teoria dos direitos fundamentais. São Paulo: Malheiros, 2008.

BARREIROS, Lorena Miranda Santos. Fundamentos constitucionais do princípio da cooperação processual. Salvador: Juspodivm, 2013.

BERALDO, Leonardo de Faria. O dever de cooperação no novo Código de Processo Civil. In: DIDIER JÚNIOR, Fredie (Coord.). Normas fundamentais. Salvador: Juspodivm, 2016. Coleção Grandes Temas do Novo CPC, v. 8. 
BRASIL. Constituição Federal. Brasília: Senado Federal, 1988.

BRASIL. Lei no 5.869, de 11 de janeiro de 1973. Institui o Código de Processo Civil. Diário Oficial da República Federativa do Brasil, Brasília, DF, 17 jan. 1973. Disponível em: <http:// www.planalto.gov.br/ccivil_03/leis/15869compilada.htm>. Acesso em: 20 jun. 2016.

BRASIL. Lei no 13105, de 16 de março de 2015. Institui o Código de Processo Civil. Diário Oficial da República Federativa do Brasil, Brasília, DF, 17 mar. 2015. Disponível em: <http://www. planalto.gov.br/CCIVIL_03/_Ato2015-2018/2015/Lei/L13105.htm>. Acesso em: 22 jun. 2016.

CÂMARA, Alexandre Freitas. Lições de direito processual civil. 21. ed. Rio de Janeiro: Lumen Juris, 2011. v. 1.

CAMBI, Eduardo. Neoconstitucionalismo e neoprocessualismo: direitos fundamentais, políticas públicas e protagonismo judiciário. 2. ed. rev. e atual. São Paulo: Revista dos Tribunais, 2011.

CANOTILHO, José Joaquim Gomes. Direito constitucional e teoria da constituição. 7. ed. Coimbra: Almedina, 2003.

CAPPELLETTI, Mauro; GARTH, Bryant. Acesso à justiça. Traduzido por Ellen Gracie Northfleet. Porto Alegre: Fabris, 1988. Tradução de: Access to justice.

CERQUEIRA, Dhebora Mendonça de; MACHADO JÚNIOR, Arnaldo de Aguiar. Adaptabilidade no projeto do Novo Código de Processo Civil. Revista da Esmese, Aracaju, n. 17, p. 111137, jun. 2012.

CINTRA, Antonio Carlos de Araújo; DINAMARCO, Cândido Rangel; GRINOVER, Ada Pellegrini. Teoria Geral do Processo. 25. ed. rev. e atual. São Paulo: Malheiros, 2009.

CRAMER, Ronaldo. O princípio da boa-fé objetiva no novo CPC. In: DIDIER JÚNIOR, Fredie (Coord.). Normas fundamentais. Salvador: Juspodivm, 2016. Coleção Grandes Temas do Novo CPC, v. 8.

DELFINO, Lúcio. Cooperação processual no novo CPC pode incrementar o ativismo judicial. Revista Consultor Jurídico, 02 maio 2016. Disponível em: <http://www.conjur.com.br/2016mai-02/cooperacao-processual-cpc-incrementar-ativismo-judicial> Acesso em: 16 jul. 2016.

DELFINO, Lúcio; LIMA, Danilo Pereira; LOPES, Ziel Ferreira; STRECK, Lenio Luiz. O papel do jurista em face da crise política e institucional brasileira. Revista Consultor Jurídico, 25 jan. 2016. Disponível em: <http://www.conjur.com.br/2016-jan-25/papel-jurista-face-crisepolitica-institucional>. Acesso em: 16 jul. 2016.

DIDIER JÚNIOR, Fredie. Curso de direito processual civil: introdução ao direito processual civil, parte geral e processo de conhecimento. 17. ed. Salvador: Juspodivm, 2015, v. 1.

DIDIER JÚNIOR, Fredie. Princípio da cooperação. In: DIDIER JÚNIOR, Fredie (Coord.). Normas fundamentais. Salvador: Juspodivm, 2016. Coleção Grandes Temas do Novo CPC, v. 8.

DWORKIN, Ronald Myles. Levando os direitos a sério. Traduzido por Nelson Boeira. São Paulo: Martins Fontes, 2002. Tradução de: Taking Rights Seriously.

FUX, Luiz. O novo processo civil. In: FUX, Luiz (Coord.). O novo processo civil brasileiro: direito em expectativa (reflexões acerca do projeto do novo Código de Processo Civil). Rio de Janeiro: Forense, 2011. 
GOUVEA, Lúcio Grassi de. Cognição processual civil: atividade dialética e cooperação intersubjetiva na busca da verdade real. In: DIDIER JR., Fredie (Org.). Leituras complementares de processo civil. 9. ed. rev. atual. e ampl. Salvador: Juspodivm, 2011.

GREGER, Reinhard. Cooperação como princípio processual. In: DIDIER JÚNIOR, Fredie (Coord.). Normas fundamentais. Salvador: Juspodivm, 2016. Coleção Grandes Temas do Novo CPC, v. 8.

KOCHEN, Ronaldo. Introdução às raízes históricas do princípio da cooperação (kooperationsmaxime). In: DIDIER JÚNIOR, Fredie (Coord.). Normas fundamentais. Salvador: Juspodivm, 2016. Coleção Grandes Temas do Novo CPC, v. 8.

MARINONI, Luiz Guilherme. Técnica processual e tutela dos direitos. São Paulo: Revista dos Tribunais, 2004.

MARINONI, Luiz Guilherme. Teoria geral do processo. 7. ed. rev. atual. e ampl. São Paulo: Revista dos Tribunais, 2013.

MENEZES, Gustavo Quintanilha Telles de. A atuação do juiz na direção do processo. In: FUX, Luiz (Coord.). O novo processo civil brasileiro: direito em expectativa (reflexões acerca do projeto do novo Código de Processo Civil). Rio de Janeiro: Forense, 2011.

MITIDIERO, Daniel. Colaboração no processo civil: pressupostos sociais, lógicos e éticos. São Paulo: Revista dos Tribunais, 2009.

MITIDIERO, Daniel; OLIVEIRA, Alvaro de. Curso de processo civil: teoria geral do processo civil e parte geral do direito processual civil. 2. ed. rev. e atual. São Paulo: Atlas, 2012. v. 1.

PEREIRA, Ruitemberg Nunes. O princípio do devido processo legal substantivo. Rio de Janeiro: Renovar, 2005.

PESSOA, Flávia Moreira Guimarães. Manual de metodologia do trabalho científico: como fazer uma pesquisa de direito comparado. Aracaju: Evocati, 2009.

PODETTI, José Ramiro. Teoría y técnica del Proceso Civil. Buenos Aires: Ediar, 1963.

TUCCI, José Rogério Cruz e. Garantias constitucionais do processo civil. In: DIDIER JÚNIOR, Fredie. Curso de direito processual civil: teoria geral do processo e processo de conhecimento. 12. ed. Salvador: Juspodivm, 2010, v. 1.

Recebido em: 28.06.2016

Pareceres: 05.07.2016 e 12.07.2016

Aprovado em: 12.07.2016

Informação bibliográfica deste texto, conforme a NBR 6023:2002 da Associação Brasileira de Normas Técnicas (ABNT):

CERQUEIRA, Dhebora Mendonça de; PESSOA, Flávia Moreira Guimarães. Direitos fundamentais processuais e o princípio da cooperação no novo Código de Processo Civil. Direitos Fundamentais \& Justiça, Belo Horizonte, ano 10, n. 34, p. 295-315, jan./jun. 2016. 